Departement für Nutztiere der Vetsuisse-Fakultät

Universität Zürich

Klinik für Fortpflanzungsmedizin

(Direktor: Prof. Dr. W. Kähn) und

BIG-X AG Seewen

\title{
Fertility in heifers and cows after low dose insemination with sex-sorted and non-sorted sperm under field conditions
}

\section{INAUGURAL-DISSERTATION}

zur Erlangung der Doktorwürde der Vetsuisse-Fakultät

Universität Zürich

vorgelegt von

Michèle Bodmer

Tierärztin

von Rehetobel

Genehmigt auf Antrag von

Prof. Dr. R. Thun, Referent

Prof. Dr. G. Stranzinger, Korreferent 


\title{
Fertility in heifers and cows after low dose insemination with sex-sorted and non-sorted sperm under field conditions
}

\author{
M. Bodmer ${ }^{\mathrm{a}}$, F. Janett ${ }^{\mathrm{b}}$, M. Hässig ${ }^{\mathrm{b}}$, N. den Daas ${ }^{\mathrm{a}}$, P. Reichert ${ }^{\mathrm{a}}$, R. Thun ${ }^{\mathrm{b}}$ \\ ${ }^{\mathrm{a} B i g-X}$ Inc., Seewen, ${ }^{\mathrm{b}}$ Clinic of Reproduction, University of Zürich, Switzerland
}

\begin{abstract}
The present study was performed to test fertility after low dose insemination with sexed and non-sexed sperm in dairy cattle under field conditions in Switzerland. Spermatozoa were stained with Hoechst 33342 and sorted by flow cytometry. A total of 132 heifers and cows were inseminated with $2 \times 10^{6}$ x-bearing, frozen-thawed sperm (A) and 91 animals were inseminated with the same dose using non-sorted, frozen-thawed sperm (B). Pregnancy examination by ultrasound was performed twice, 30 to 40 days (PE1) and 70 to 90 days (PE2) after insemination. The pregnancy rates after PE1 were 33.3\% (9/27) and 59.3\% (16/27) in heifers $(\mathrm{P}=0.05)$ and $27.6 \%(29 / 105)$ and $28.1 \%(18 / 64)$ in cows $(\mathrm{P}>0.05)$ for groups $\mathrm{A}$ and $\mathrm{B}$, respectively. Embryonic losses between PE1 and PE2 in heifers were 11.1\% (1/9) and $0 \%$ $(0 / 16)$ and in cows $17.2 \%(5 / 29)$ and $5.6 \%(1 / 18)$, the differences between groups A and B not being significant $(\mathrm{P}>0.05)$. Calving rates in heifers were 29.6\% (8/27) and 57.8\% (15/26), whereas in cows $22.1 \%$ (23/104) and 23.4\% (16/63) gave birth to calves (for both groups $\mathrm{P}>0.05)$. The sex ratio was different $(\mathrm{P}<0.05)$ between $\mathrm{A}(85.3 \%)$ and $\mathrm{B}(58.6 \%)$. From our results it can be concluded that conception rates of sorted and non-sorted semen are similar using an insemination dose of $2 \times 10^{6}$. Fertility may be increased by improving sexing technology and animal management.
\end{abstract}

Keywords: sexed semen, low dose insemination, cows, heifers, fertility 


\section{Fertilität von Rindern und Kühen unter Feldbedingungen nach Besamung mit gesextem und nicht gesextem Samen in niedriger Dosis}

Samen von 4 Brown Swiss und 2 Red Holstein Stieren wurde mit Hoechst 33342 gefärbt und anschliessend mittels Durchflusszytometrie nach Geschlecht (X und Y Chromosom) sortiert. Insgesamt 132 Rinder und Kühe wurden mit $2 \times 10^{6}$ gesexten und gefrorenen Spermatozoen (Gruppe A) und 91 Tiere wurden mit 2 × $10^{6}$ ungesexten und gefrorenen Spermatozoen (Gruppe B) besamt. Trächtigkeitsuntersuchungen wurden 20-40 Tage (TU 1) und 70-90 Tage nach der Besamung (TU 2) mittels Ultraschall durchgeführt. Trächtigkeitsraten bei den Rindern nach TU 1 betrugen 33,3\% für Gruppe A und 59,3\% für Gruppe B (P=0,05). Bei den Kühen ergaben sich Trächtigkeitsraten von 27,6\% für Gruppe A, respektive 28,1\% für Gruppe B(P > 0,05). Bei den Rindern der Gruppe A wurden 11.1\% Aborte zwischen TU 1 und TU 2 registriert, bei denjenigen der Gruppe B 0\% (P > 0,05). Bei den Kühen der Gruppe A fanden sich 17,2\% Aborte zwischen TU 1 und TU 2, bei Gruppe B 5,6\% (P > 0,05). Die Abkalberaten unterschieden sich weder bei den Kühen noch bei den Rindern signifikant zwischen den Gruppen A und B (P > 0,05). Deutlich mehr weibliche Kälber wurden in Gruppe A (85,3\%) als in Gruppe B (58,6\%) geboren $(\mathrm{P}<0,05)$. 


\section{Introduction}

Until now, the only reliable method for separating $\mathrm{X}$ - and Y-chromosome-bearing spermatozoa is flow cytometrical cell sorting for DNA content of sperm. The first live offspring from flow cytometrically sorted sperm resulted from rabbits surgically inseminated into the oviduct (1). From then on, offspring of preselected sex have been produced with an accuracy close to $90 \%$ in pigs $(2,3,4)$, cattle $(5,6,7,8)$, horses $(9,10)$ and humans $(11)$. Due to improvement of nozzle design (12) and adaptation to high-speed cell sorting (13) the efficiency of the sexing procedure has increased considerably. Accuracy of the desired sex ranges from $85 \%$ to $90 \%$ and sorting speed has been established at up to $11 \times 10^{6}$ sperm cells per hour (13). The sexing method has also been combined with in vitro fertilization in pigs $(2,3)$ and cattle $(14,15)$. To make sorted sperm available for artificial insemination on a commercial basis, experiments using low dose insemination with flow-sorted sperm were performed in horses $(9,10)$, cattle $(6,7)$, sheep $(16)$ and pigs $(4,17)$. In addition, it is known that during sorting with the flow cytometer, dead sperm cells are not sorted, and therefore not loaded into straws (18).

To increase fertility, uterine horn insemination with sorted frozen-thawed sperm was tested in cattle (6). Results of these experiments did not show a significant increase of pregnancy rates compared with uterine body insemination, although some authors (19) claim to have better results when performing uterine horn insemination with non-sorted sperm. Seidel et al. (6) combined sorted, liquid semen with very low dose ( 1 to $2 \times 10^{5}$ in $0.1 \mathrm{~mL}$ ) insemination into the uterine horn ipsilateral and contralateral to the ovary bearing the largest follicle. Pregnancy rates for ipsilateral and contralateral inseminations were nearly identical and ranged from $2.6 \%$ to $22.4 \%$, depending on the time between the end of sorting and insemination as well as on the bull used. A recent study in pigs (4) shows, that low dose $(70 \mathrm{x}$ $10^{6}$ spermatozoa) insemination with flow cytometrically sorted sperm deep into the uterine horn resulted in pregnancy rates of $45.6 \%$ and $35 \%$ for induced and spontaneous ovulation, respectively. In horses, hysteroscopic insemination into the uterine horn $(10,20)$ and ultrasound guided deep uterine insemination $(9,20)$ were performed using sex-sorted sperm in low concentrations ( $5 \times 10^{6}$ sperm cells per dose). Hysteroscopic insemination resulted in more pregnancies than ultrasound guided deep uterine insemination $(10,20)$.

Reduced fertility, when using sorted sperm, has been attributed to damage of spermatozoa caused by the sexing process (18). This includes staining and incubation of spermatozoa with Hoechst 33342, sperm dilution, exposure to high pressure and laser light, the rapid projection into the collection tube and also centrifugation to concentrate sorted sperm. After sorting, 
spermatozoa are partially capacitated resulting in a shorter life span and consequently in reduced fertilizing capacity (4). To increase sperm quality and fertility of sexed sperm, Seidel et al. (21) as well as Suh and Schenk (22) showed that post thaw motility and fertility were considerably higher when lower pressure was used during sorting. This however, reduces the sorting rate by 2 to 3\% (22). Embryo survival rates were also impaired with sorted sperm in cattle (6), pigs (4), mares (9) and rabbits (23) when compared with non-sorted sperm but calves produced with sexed sperm were not different from control calves regarding birth weight, mortality and weaning weight $(24,25)$. Furthermore no differences were observed between cows carrying calves derived from sorted or non-sorted sperm when comparing gestation length, abortion rate and calving ease (25).

Since little information exists about low dose insemination with sexed sperm in Switzerland the objective of the present study was to evaluate fertility in heifers and cows inseminated with low numbers of sexed and non-sexed frozen-thawed sperm under field conditions.

\section{Material and methods}

\subsection{Semen collection and quality control}

For this study semen of seven bulls of different ages and breeds (5 Brown Swiss, 2 Red Holstein) was collected using an artificial vagina. After collection, sperm concentration was determined with a spectrophotometer (Co75 Colorimeter, WPA, Cambridge, UK). Mass motility and progressive sperm motility were evaluated subjectively by phase contrast microscopy (CX 40 Olympus, Volketswil, Switzerland). Only ejaculates with a concentration of more than $800 \times 10^{6}$ spermatozoa per milliliter and a progressive motility of at least $80 \%$ were further processed. Thereafter, ejaculates were divided in half to produce sex-sorted sperm and non-sorted sperm. The percentage of ejaculates from all seven bulls fulfilling the above criteria varied between $25 \%$ and $64 \%$.

\subsection{Flow cytometric sorting of sperm}

Sperm sorting was performed with a MoFlo® ${ }^{\circledR}$ SX (Cytomation, Inc., Fort Collins, USA) equipped with an Argon laser, detectors for fluorescence and a special spermatozoa oriented nozzle developed by Rens et al. (12). An aliquot of freshly collected semen was diluted in staining medium (modified Tyrode's albumin lactate Pyruvate $=$ TALP) to a concentration of $200 \times 10^{6}$ spermatozoa/mL followed by staining with Hoechst 33342 for $60 \mathrm{~min}$ at $37^{\circ} \mathrm{C}$. The sample was diluted in the sorting medium (TALP containing 20\% egg yolk) and vital-staining food dye (Sigma-Aldrich, Fluka Chemie GmbH, Buchs, Switzerland) was added to mark 
sperm cells with ruptured membranes (18). During sorting at room temperature (90 min), spermatozoa in the sorting medium were mixed with a TRIS-based sheath fluid containing citric acid and fructose. Sperm cells showing fluorescence when excited by the Argon laser passed two detectors at $90^{\circ}$ to each other, one to diagnose correct orientation and the other to measure strength of fluorescence. According to the amount of emitted fluorescent light the spermatozoa were given an electric charge, i.e. X-bearing sperm were negatively charged and attracted to the positive field on the right, while Y- bearing-sperm as well as badly oriented spermatozoa and cells with ruptured membranes containing food coloring, were not electrically charged and ended in a waste tube (18).

Sorted spermatozoa were collected into tubes containing catch fluid (22\% egg yolk-TRISextender), allowed to equilibrate at $5^{\circ} \mathrm{C}$ for a minimum of $90 \mathrm{~min}$ and centrifuged at $85 \mathrm{x} \mathrm{g}$ for $20 \mathrm{~min}$. After resuspension with TRIS-based extender, concentration was assessed using an improved Neubauer hemocytometer and brought to the final concentration of $8 \times 10^{6}$ spermatozoa/mL by adding Tris based extender containing glycerol. The sample, with a final concentration of $6 \%$ glycerol, was kept in a cooling cabinet at $5{ }^{\circ} \mathrm{C}$ until packaging. The nonsorted portion of an ejaculate was diluted to a concentration of $16 \times 10^{6}$ spermatozoa/mL with TRIS-based extender and then cooled down to $5^{\circ} \mathrm{C}$. Finally, the non-sorted ejaculate fraction was diluted to a concentration of $8 \times 10^{6}$ spermatozoa/mL with TRIS-based extender containing glycerol.

\subsection{Further processing and freezing}

Sorted and non-sorted sperm were packaged at the same time in $0.25 \mathrm{~mL}$ French straws (IMV, Aigle, France), each containing $2 \times 10^{6}$ spermatozoa. After packaging, straws were kept on freezing racks at $5^{\circ} \mathrm{C}$ for 3 to 4 hours and then frozen in an automatic freezer (No. 5109, Nifa Instrumenten BV, Leeuwarden, The Netherlands) and stored in liquid nitrogen at $196^{\circ} \mathrm{C}$. After freezing, one straw of each batch was thawed at $38^{\circ} \mathrm{C}$ for $20 \mathrm{sec}$ and quality parameters were established. Sexed semen with less than $15 \%$ progressive motility and control doses with less than 30\% progressive motility were discarded. In addition, one straw of each sorted batch was sonicated and analyzed by flow cytometry to determine accuracy of sorting which was required to be greater than $85 \%$.

\subsection{Artificial insemination}

Artificial insemination (AI) was performed by professional personnel, including one technician and five veterinarians. Animals were inseminated 12 hours after the occurrence of 
standing heat and were not synchronized. Inseminators were blind to whether they were using sorted or non-sorted straws. Straws were thawed at $38^{\circ} \mathrm{C}$ for $20 \mathrm{sec}$ and inseminations were performed into the uterine body.

\subsection{Field study}

For this study, a total of 27 heifers and 105 cows (up to lactation number 4) were inseminated with sex-sorted, frozen-thawed sperm (group A) and 27 heifers and 64 cows (up to lactation number 4) with non-sorted, frozen-thawed sperm (group B). Cows were between 40 and 90 days post partum. All straws used in this trial contained $2 \times 10^{6}$ spermatozoa.

Heifers and cows of the Brown Swiss and the Red Holstein breeds were scattered on 117 farms in different regions of Switzerland. Because of heterogeneous farm structures with very low numbers of animals per farm, parameters such as milk yield, body condition and feeding program were not recorded in this study. Problem animals, defined as females with impaired function of the genital tract, severe foot problems or systemic illness were not inseminated. Since inseminations have been performed from July 2002 to February 2003 seasonal influences could not be excluded. All animals not returning to estrus 21 days after insemination were examined by ultrasound (Tringa, Esoate Pie Medical, Maastricht, The Netherlands) for pregnancy 30 to 40 days after insemination (PE1). Pregnant animals were reexamined sonographically between 70 and 90 days after insemination (PE2). Failure to confirm pregnancy at PE2 represented embryonic loss. Animals returning to service or not being pregnant when examined 30 to 40 days after insemination were not further evaluated. Calving ease, possible dystocias and sex of the newborn calves were recorded by information provided by the farmers.

\subsection{Statistical analysis}

Statistic analysis was performed with Stat View 5.0® (SAS Institute, Wangen, Switzerland ). A Chi-Square-test was performed to compare rates of pregnancy, abortion and calving between treatments. In addition, a logistic regression model was used to analyze the effects of animals, bull, inseminator and treatment on pregnancy, abortion and calving. Differences were considered significant at $\mathrm{P}<0.05$.

\section{Results}

When analyzing fertility data of all animals including heifers and cows ( $\mathrm{n}=223$ ), no significant difference $(\mathrm{P}>0.05)$ could be observed between groups $\mathrm{A}$ and $\mathrm{B}$. The conception 
rate 30 to 40 days after insemination (PR1) was 28.8\% using sex-sorted sperm (group A) and 27.4\% for non-sorted sperm (group B). At 70 to 90 days after insemination pregnancy rates (PR2) were $24.2 \%$ and $36.3 \%$ for sexed and non-sexed sperm, respectively ( $\mathrm{P}>0.05$ ). Embryonic loss was calculated to be $15.8 \%$ for group A and $2.9 \%$ for group B (P > 0.05) and the calving rate was $23.5 \%$ and $33.0 \%$ for group $\mathrm{A}$ and $\mathrm{B}$, respectively $(\mathrm{P}>0.05)$. Given the fact that fertility in heifers is generally higher than in cows, data presented in Table 1 were separately analyzed for heifers and cows.

Tab. 1. Pregnancy rates (PR), abortion rates (AR) and calving rates (CR) in heifers and cows inseminated with sex-sorted (A) and non-sorted (B) semen.

\begin{tabular}{lccccccccc}
\hline \multirow{2}{*}{ Group } & \multirow{3}{*}{ Animals } & $\begin{array}{c}\text { Pregnant at } \\
\text { PE1 }\end{array}$ & $\begin{array}{c}\text { PR1 } \\
\%\end{array}$ & $\begin{array}{c}\text { Pregnant at } \\
\text { PE2 }\end{array}$ & $\begin{array}{c}\text { PR2 } \\
\%\end{array}$ & $\begin{array}{c}\text { Embryonic } \\
\text { loss }\end{array}$ & $\begin{array}{c}\text { AR } \\
\%\end{array}$ & $\begin{array}{c}\text { Animals } \\
\text { calving }\end{array}$ & $\begin{array}{c}\text { CR } \\
\%\end{array}$ \\
\hline A & 132 & 38 & 28.8 & 32 & 24.2 & 6 & 15.8 & 31 & 23.7 \\
B & 91 & 34 & 37.4 & 33 & 36.3 & 1 & 2.9 & 31 & 34.8 \\
Heifers A & 27 & 9 & $33.3^{\mathrm{a}}$ & $8^{1)}$ & $29.6^{\mathrm{a}}$ & 1 & 11.1 & 8 & 29.6 \\
Heifers B & 27 & 16 & $59.3^{\mathrm{b}}$ & 16 & $59.3^{\mathrm{b}}$ & 0 & 0.0 & $15^{2)}$ & 57.8 \\
Cows A & 105 & 29 & $27.6^{\mathrm{a}}$ & $24^{3)}$ & $23.8^{\mathrm{a}}$ & 5 & 17.2 & $23^{3)}$ & 22.1 \\
Cows B & 64 & 18 & $28.1^{\mathrm{c}}$ & $17^{4)}$ & $26.6^{\mathrm{c}}$ & 1 & 5.6 & $16^{4)}$ & 23.4 \\
\hline
\end{tabular}

PR 1= Pregnancy rate 30 to 40 days after insemination, PR 2= Pregnancy rate 70 to 90 days after insemination

1) One heifer lost its embryo between PE 1 and PE 2

2) One heifer died before calving

3) Five cows lost their embryos between PE 1 and PE 2 and one animal was sold before calving

4) One cow lost its embryo between PE 1 and PE 2 and another was slaughtered before calving.

a,b,c different letters within a column indicate statistically significant differences $(\mathrm{P}<0.05)$ 
In heifers, pregnancy rates at 30 to 40 days (PR1) and 70 to 90 days (PR2) after insemination were significant $(P=0.05)$ between groups $A(33.3 \%, 9 / 27)$ and $B(59.3 \%, 16 / 27)$. Comparing pregnancy results between heifers and cows a clear difference could only be detected in group $\mathrm{B}(\mathrm{P}=0.005)$. In group $\mathrm{A}$, one heifer out of nine $(11.1 \%)$ lost its embryo between PE1 and PE2 compared to none out of 16 in group $\mathrm{B}(\mathrm{P}>0.05)$. Calving rate in heifers was not significantly different $(P=0.098)$ between group A $(29.6 \%, 8 / 27)$ and $B$ (57.8\%, 15/26).

In cows, pregnancy rates after PE1 did not differ $(\mathrm{P}>0.05)$ between group $\mathrm{A}(29 / 105,27.6 \%)$ and B (18/64, 28.1\%), respectively and also for PR2 the difference between group A (23.8\%, $24 / 105)$ and B (26.6\%, 17/64) was not significant ( $\mathrm{P}>0.05)$. The percentage of embryonic loss in cows between PE1 and PE2 was 17.2\% (5/29) in group A and 5.6\% (1/18) in group B $(\mathrm{P}=0.40)$ and calving rates were 22.1\% (23/104) and 23.4\% (15/64) for groups A and B, respectively $(\mathrm{P}>0.05)$.

With the exception of one bull with a significant $(\mathrm{P}=0.04)$ effect on pregnancy rates of heifers in group B, the effects of season, breed, number of lactation (tested only in cows) and inseminator on pregnancy rates, embryonic loss and calving rate were not significant $(\mathrm{P}>$ 0.05). When comparing the calving rate with the PR2 in heifers as well as in cows, no significant difference could be detected $(\mathrm{P}>0.05)$. When determining the sex of the newborn calves more female calves ( $\mathrm{P}<0.05)$ were born in group A $(29 / 34,85.3 \%)$ than in group B $(17 / 28,58.6 \%)$ and more twins $(\mathrm{P}<0.05)$ were born in group $\mathrm{A}$ than in group $\mathrm{B}$. Between PE2 and term no fetal malformation or abortions occurred in heifers and cows.

\section{Discussion}

Compared to Seidel et al. (7) our pregnancy rates obtained from inseminations with a dose of $2 \times 10^{6}$ spermatozoa into the uterine body were low, irrespective whether sex-sorted or nonsorted sperm was used. In cows, pregnancy rates were lower than $30 \%$ and did not differ between groups A (sorted) and B (non-sorted) indicating that the total number of spermatozoa inseminated seems to be more detrimental for conception than the use of sexed or non-sexed sperm. This also agrees with findings of Andersson et al. (26), who reported significantly lower conception rates using $2 \times 10^{6}$ spermatozoa per dose compared to $15 \times 10^{6}$ spermatozoa per dose. We have to take into account, that the sorted cells are not only sorted for sex, but are also sorted for membrane integrity, thus only vital cells are sorted.

In heifers, using the same insemination dose as in cows, conception rate with sex-sorted sperm was not significantly different from cows (33.3\% vs. 27.6\%), but was clearly increased 
when non-sorted sperm was used (59.3\% vs. 28.1\%). In the US, Seidel et al. (7) reported conception rates in heifers around 50\% when using sex-sorted sperm at doses between 0.3 and $3.0 \times 10^{6}$. These results might be compared to data obtained by another study (unpublished data) of Big-X, Switzerland, including heifers (47\%) and lactating cows (32\%) with an insemination dose of $2 \times 10^{6}$ sexed sperm. A possible cause for the low pregnancy rates in heifers with sex-sorted sperm in the present experiment may be the combination of the low insemination dose together with low post thaw motility, the fragility of sorted spermatozoa and the heterogeneous management conditions including estrus detection, timing of $\mathrm{AI}$ as well as the feeding and animal health programs. This agrees with the work of Seidel (8) who also found low conception rates if management conditions were not optimal. In contrast, pregnancy rates in heifers using non-sorted sperm were nearly 60\% corresponding with calculated results of Den Daas et al. (27) when using the same insemination dose of $2 \times 10^{6}$. In addition, these results were found to strongly depend on the bull used for insemination. Therefore, caution must be applied when interpreting our results with non-sorted sperm in heifers as one bull clearly influenced pregnancy rates of heifers in group B. The strong influence of individual bull fertility has also been confirmed by Seidel et al. (6).

Regarding embryonic loss between PE1 and PE2, the percentages in cows and heifers were higher when using sex-sorted sperm (17.2\% vs. 11.1\%), than non-sorted sperm (0\% vs. 5.6\%). These values, however, are lower when comparing to findings of Seidel et al. (6) who reported 23\% of abortions between one and two months of gestation using sexed liquid sperm in heifers. The increased abortion rate during the first two to three months of gestation may be caused by treating sperm with DNA-binding fluorescent stain and damaging spermatozoa during flow cytometry. This hypothesis, however, has to be confirmed in future studies using a larger number of animals. Interestingly enough, abortions after three months of gestation or malformations in newly born calves were not observed in our study as well as in other studies $(6,24,25)$ and a recent study including large numbers of animals inseminated with sorted semen reported abortion rates between 2 months of gestation and term of $4 \%$ and $2.4 \%$ for female and male calves, respectively (25).

According to Seidel et al. (7) higher conception rates were obtained when inseminating $3 \mathrm{x}$ $10^{6}$ spermatozoa compared to $1.5 \times 10^{6}$ spermatozoa per dose under heterogeneous field conditions. Den Daas et. al. (27) calculated that for most bulls, the limiting sperm concentration to obtain around $80 \%$ of the normal conception rate is around $2 \times 10^{6}$ sperm cells per dose. Whether this is also applicable on flow cytometrically sorted sperm needs to be determined. In pigs (4) pregnancy rates of $45.6 \%$ and $54.3 \%$ were recorded with $70 \times 10^{6}$ and 
$140 \times 10^{6}$ sexed spermatozoa in combination with deep uterine insemination. In horses (20), the limiting sperm concentration is considered to be around $5 \times 10^{6}$ spermatozoa per dose, if either hysteroscopic or deep uterine insemination techniques are applied. Comparing data across species, it seems that in the bull a dose of 2 to $3 \times 10^{6}$ spermatozoa is too low to obtain pregnancy rates around $80 \%$ of the normal.

As expected, the percentage of female calves born in group A was significantly $(\mathrm{P}<0.05)$ higher than in group B which clearly demonstrates that flow-cytometric sorting of semen is a reliable method for sex-preselection in the bovine.

From our field study we can draw the conclusion that conception rates are similarly low when using sorted and non-sorted semen at doses of $2 \times 10^{6}$ spermatozoa. We therefore suggest that fertility may be increased by selection of sires, improving the management of the female as well as optimizing the sorting process, cryopreservation and the insemination technique. For correct insemination time intense estrus control without or with facilitating devices, such as electronic mounting detectors (28) is required. This seems to be very crucial, especially when using sex-sorted spermatozoa, which are known to be partially capacitated before insemination and thus may negatively affect fertilization success especially when insemination time was inappropriate. Rankin et al. (29) investigated the periovulatory events in dairy heifers over three years and found that the time interval between onset of estrus and ovulation had a significant effect on conception rate. Walker et al. (30), using an electronic mounting detection system reported that ovulation takes place within $27 \mathrm{~h}$ after observation of first mount. To facilitate optimal insemination time, estrus synchronizing protocols should be tested in combination with sex-sorted sperm (31). Another important point influencing semen quality and conception results is the system pressure during flow-sorting, which has not yet been adjusted to the improved and lower level of 30 psi (22). Following the sorting procedure an optimal cooling rate at freezing (32) and careful handling of frozen semen by inseminators (33) are also necessary. Improvement of deep uterine insemination techniques with modern flexible catheters to bring spermatozoa closer to the functional sperm reservoir in the caudal portion of the Fallopian tube should be the goal of future experiments (34). This, however, requires also the necessity for adequate training of veterinarians and AI technicians.

In summary, from our data it can be concluded that conception rates between sorted and nonsorted semen inseminated at doses of $2 \times 10^{6}$ are similar. Fertility may be increased by improving several factors such as careful selection of AI bulls, accurate estrus detection and time of insemination as well as optimized semen processing, handling and insemination technique. 


\section{Acknowledgements}

We thank the veterinarians and AI technicians for performing the inseminations and the staff of BIG-X for processing the semen. We also are grateful to all farmers who supported us in this study.

\section{References}

(1) Johnson LA, Flook JP, Hawk HW. Sex preselection in rabbits: Live birth from X and Y sperm seperated by DNA and cell sorting. Biol Reprod 1989;41:199-203.

(2) Abeydeera LR, Johnson LA, Welch GR, Wang WH, Boquest AC, Cantley TC, Rieke A, Day BN. Birth of piglets preselected for gender following in vitro fertilization of in vitro matured pig oocytes by $\mathrm{X}$ and $\mathrm{Y}$ chromosome bearing spermatozoa sorted by high speed flow cytometry. Theriogenology 1998;50:981-988.

(3) Rath D, Johnson LA, Dobrinsky JR, Welch GR, Niemann H. Production of piglets preselected for sex following in vitro fertilization with $\mathrm{X}$ and $\mathrm{Y}$ Chromosome-bearing spermatozoa sorted by flow cytometry. Theriogenology 1997;47:795-800.

(4) Vazquez JM, Martinez EA, Parilla I, Roca J, Gil MA, Vazquez JL. Birth of piglets after deep intrauterine insemination with flow cytometrically sorted boar spermatozoa. Theriogenology 2003;59:1605-1614.

(5) Hamano K, Li X Qian X, Funauchi K, Furudate M, Minato Y. Gender preselection in cattle with intracytoplasmatically injected, flow cytometrically sorted sperm heads. Biol Reprod 1999;60:1194-1197.

(6) Seidel GE Jr, Allen CH, Johnson LA, Holland MD, Brink Z, Welch GR, Graham JK, Cattell MB. Uterine horn insemination of heifers with very low numbers of nonfrozen and sexed spermatozoa. Theriogenology 1997;48:1255-64.

(7) Seidel GE Jr, Schenk JL, Herickhoff LA, Doyle SP, Brink Z, Green RD, Cran DG. Insemination of heifers with sexed sperm. Theriogenology 1999;52:1407-1420.

(8) Seidel GE Jr. Economics of selecting for sex: the most important genetic trait. Theriogenology 2003;59:585-598.

(9) Buchanan BR, Seidel GE Jr, McCue PM, Schenk JL, Herickhoff LA, Squires EL. Inseminations of mares with low numbers of either unsexed or sexed spermatozoa. Theriogenology 2000;53:1333-1344.

(10) Lindsey AC, Schenk JL, Graham JK, Bruemmer JE, Squires EL. Hysteroscopic insemination of low numbers of non sorted or flow sorted spermatozoa. Equine Vet $\mathrm{J}$ 34:128-132. 
(11) Fugger EF, Black SH, Keyvanfar K, Schulman JD. Birth of normal daughters after MicroSort sperm separation and intrauterine insemination, in-vitro fertilization, or intracytoplasmic sperm injection. Human Reprod 1998;13:2367-2370.

(12) Rens W, Welch GR, Johnson LA. Improved flow cytometric sorting of X- and Y bearing sperm: Substantial increase in yield of sexed semen. Mol Reprod Dev 1999;52:50-56.

(13) Johnson LA, Welch GR: Sex preselection: high-speed flow cytometric sorting of X and Y bearing sperm for maximum efficiency. Theriogenology 1999;52:1323-42.

(14) Johnson LA, Cran DG, Polge C. Recent advances in sex preselection of cattle: Flow cytometric sorting of X-and Y-chromosome bearing sperm based on DNA to produce progeny. Theriogenology 1994;41:51-56.

(15) Lu KH, Cran DG, Seidel GE Jr. In vitro fertilization with flow-cytometrically-sorted bovine sperm. Therigenology 1999;52:1393-1405.

(16) Maxwell WMC, Evans G, Hollinshead FK, Bathgate R, de Graaf SP, Eriksson BM, Gillian L, Morton KM, O’Brien JK. Integration of sperm sexing technologiy into the ART toolbox. Anim Reprod Sci 2004;82-83:79-95.

(17) Rath D. Low dose insemination in the sow: A review. Reprod Dom Anim 2002;37:201205.

(18) Seidel GE, Jr, Garner DL. Current status of sexing mammalian spermatozoa. Reproduction 2002;124:711-714.

(19) Lòpez-Gatius F. Site of semen deposition in cattle: A review. Theriogenology 2000;53:1407-1414.

(20) Morris LH, Allen WR. An overview of low dose insemination in the mare. Reprod Dom Anim 2002;37:206-210.

(21) Seidel GE Jr, Brink Z, Schenk JL. Use of heterospermic insemination with fetal sex as the genetic marker to study fertility of sexed sperm. Theriogenology 2003;59:515 (abstract).

(22) Suh TK, Schenk JL. Pressure during sorting of bull sperm affects post-thaw motility characteristics. Theriogenology 2003;59:516 (abstract).

(23) Mc Nutt TL, Johnson LA: Flow cytometreic sorting of sperm: influence of fertilization and embryo/fetal development in the rabbit. Mol Reprod Dev 1996 Feb;43(2):261-267.

(24) Tubman LM, Brink Z, Suh T-K, Seidel GE Jr. Normality of calves resulting from sexed sperm. Theriogenology 2003;59:517 (abstract). 
(25) Tubman LM, Brink Z, Suh TK, Seidel GE Jr. Characteristics of claves produced with sperm sexed by flow cytometry/cell sorting. J Anim Sci 2004;82:1029-1036.

(26) Andersson M, Juhani T, Koskinen E, Dahlbom M. Effect of insemination with doses of 2 or 15 million frozen-thawed spermatozoa and semen deposition site on pregnancy rate in dairy cows. Theriogenology 2004;61:1583-1588.

(27) Den Daas JH, De Jong G, Lansbergen LMTE, Van Wagtendonk AM. The relationship between the number of spermatozoa inseminated and the reproductive efficiency of individual dairy bulls. J Dairy Sci 1998;81:1714-1723.

(28) $\mathrm{Xu} \mathrm{ZZ,} \mathrm{McKnight} \mathrm{R,} \mathrm{Vishwanath} \mathrm{R,} \mathrm{Pitt} \mathrm{CJ,} \mathrm{Burton} \mathrm{LJ.} \mathrm{Estrus} \mathrm{detection} \mathrm{using}$ radioelementary or visual observation and tail painting for dairy cows on pasture. $\mathrm{J}$ Dairy Sci 1998;81:2890-2896.

(29) Ranking TA, Smith WR, Shanks RD, Lodge JR. Timing of insemination in dairy heifers. J Dairy Sci 1992;75:2840-2845.

(30) Walker WL, Nebel RL, McGilliard ML. Time of ovulation relative to mounting activity in dairy cattle. J Dairy Sci 1996;79:1555-1561.

(31) Cartmill JA, El-Zarkouny SZ, Hensley BA, Lamb GC, Stevenson JS. Stage of cycle, incidence, and timing of ovulation and pregnancy rates in dairy cattle after three timed breeding protocols. J Dairy Sci 2001;84:1051-1059.

(32) Woelders H. Fundamentals and recent development in cryopreservation of bull and boar semen. Vet Q 1997;19(3):135-138.

(33) Barth AD. Factors affecting fertility with artificial insemination. Vet Clin North Am Food Anim Pract 1993;9:275-289.

(34) Hunter RHF, Greeve T. Deep uterine insemination of cattle: A fruitful way forward with smaller numbers of spermatozoa. Acta Vet Scand 1998;39:149-163. 


\section{Lebenslauf}

Name

Geburtsdatum

Geburtsort

Nationalität

Heimatort

$1981-1987$

$1987-1994$

$1995-2001$

2001

2001

$2002-2004$

Seit 2004

12.03.2005
Michèle Catherine Bodmer

16.1.1975

Luzern

Schweiz

Rehetobel AR

Primarschule in Luzern

Kantonsschule Alpenquai Luzern, Matura Typus B

Studium der Veterinärmedizin, Universität Bern, Schweiz

Praktikum im Bereich Large Animal Surgery, Cornell University, Ithaca, USA

Staatsexamen an der Veterinärmedizinischen Fakultät der Universität Bern, Schweiz

Tierärztin bei der BIG-X AG in Seewen, SZ

Tierärztin in der Tierarztpraxis am Rössliplatz, Dagmersellen, LU 